\title{
Handling Simulation of Vehicles
}

Milan Chalupa ${ }^{1}$, Josef Veverka ${ }^{2}$

${ }^{1}$ Department of Mechanical engineering, FMT, University of defence in Brno, Czech Republic. E-mail: milan.chalupa@unob.cz.

${ }^{2}$ MSC Software s. r. o. Brno, Czech Republic. E-mail: josef.veverka@mscsoftware.com.

The article describes the vehicle passability testing possibilities by the help of computational simulation with the usage of computing simulation system ADAMS AVT. The simulation calculations can help to find quick answers to basic and additional questions of design change influences in the area of testing vehicle passability. The first part of the article contents description of partial computation simulation models construction which the calculations are associated with. The binding conditions of calculations are mentioned also. In the second part of the article, there are mentioned and evaluated the results of performed simulation calculations. These calculations are performed in order to find out an influence of operation conditions on the vehicle passability. Real operation condition is invasive vehicle speed into a slope in this case. Under investigation is the change of the gradient angle uphill maximum and beaten distance uphill that is the vehicle able to overcome.

Keywords: simulation, computational modeling

\section{Acknowledgement}

The article arose under effective supports of Partial intention for the development of organization "VÝZBROJ" (DZRO K- 201) of Faculty of Military Technology of University of defence.

\section{References}

[1] GERLICI, J., LACK, T., HARUŠINEC, J. (2013). The Test Stand Load Modulus Implementation for the Realistic Railway Operation in the Laboratory Conditions. In: Manufacturing Technology, Vol. 13, pp. 444-449, FVTM UJEP, Ústí nad Labem

[2] CHALUPA, M., VĚCHET, S., HOUFEK, L. (2010). Metodika měření rychlosti a zrychlení článku pásu pásového vozidla s využitím GPS. Vydavatelské oddělení UO, Brno, ČR.

[3] KOUCKÝ, M., VALIŠ, D. (2011). Some aspects of sequential systems design. In Proceedings $17^{\text {th }}$ ISSAT International Conference on Reliability and Quality in Design: International Society of Science and Applied Technologies, pp. 62-66. Piscataway

[4] NANGOLO, F., SOUKUP, J. (2014). The Effect of Asymmetry on Vertical Dynamic Response of Railway Vehicles. In: Manufacturing Technology, Vol. 14, pp. 375-380. FVTM UJEP, Ústí nad Labem.

[5] KLIMENDA, F., SVOBODA, M., RYCHLIKOVA, L., PETRENKO, A. (2015). Investigation of Vertical Vibration of a Vehicle Vodel Driving Through a Horizontal Curve. In: Manufacturing Technology, Vol. 15, pp. 143148. FVTM UJEP, Ústí nad Labem.

[6] LIPTÁK, P., JAMRICHOVÁ, Z., PEŠLOVÁ, F., STODOLA, P., STODOLA, J. (2011). Tools and Processes for affordable Vehicles. In: ICMT'11: International Conference on military Technologies 2011. UO Brno, Czech Republic

[7] ROKYTA, L., BILEK, O. (2012). Design of a Casting Die in CATIA. In: Manufacturing Technology, Vol. 12. FVTM UJEP, Ústí nad Labem.

[8] SKOČILAS, J., SKOČILASOVÁ, B., SOUKUP, J. (2013). Determination of the rheological properties of thin plate under transient vibration. In: Latin American Journal of Solids and Structures. Vol. 10, No. 1, pp. 187193. Society of Brasil for Mechanics and Engineering. Brasil.

[9] SVOBODA, M., SOUKUP, J. (2013). Dynamic Measurement of Four-Axle Railway Wagon, In: Manufacturing Technology, Vol. 13, pp. 552-558, FVTM UJEP, Ústí nad Labem. 